\title{
Thai Language
}

National Cancer Institute

\section{Source}

National Cancer Institute. Thai Language. NCI Thesaurus. Code C154165.

A Kra-Dai language that is spoken as the official and national language of Thailand. 